\title{
AN ALTERNATIVE VIEW OF SOUTH AFRICAN ARTILLERY
}

\section{Sgt A C Lillie*}

It has been said that 'Necessity is the mother of invention' and there can be few countries, if any, where this is more true than in South Africa.

In the late 1930's, prior to World War II, the South African Artillery was severely restricted due to its lack of mobility. The inventiveness shown in tackling this probelm is surely not a thing of the past and the possiblity of adapting South African artillery to current South african needs in warfare should not be overlooked. The South African Defence Force is not able to purchase armament in a free and open market place and the costs of developing new artillery are prohibitive in a country of South Africa's size. it will be argued that it is necessary and possible, in the short term, to take what is currently available and adapt this to South Africa's needs.

In 1938 a major advance was made in artillery transport. The guns built for horse-draught had wooden wheels, steel tyres and no springs. It was found that if they were towed faster than 10 miles per hour, the wheels collapsed and the equipment was shaken out of adjustment. The Officer Commanding Artillery School, Major M. de Villiers, saw the need for an alternative means of transporting field guns.

An eight cylinder Ford Five-ton six-wheeler, fitted with an additional gearbox, a $7 \frac{1}{2}$ ton power winch and a body designed at the Artillery School, manufactured at the Aircraft and Artillery Depot was introduced. A Q.F. 18-pounder Mark IV gun and a limber were carried on the truck, with a complete detachment, kits, and other equipment, as required for Active Service. Thirtyfour rounds of ammunition were carried in containers on the side and below the floor of the body as well as the twenty rounds which were in the limber.

This equipment was used in April 1939 on a tactical march from Roberts heights to Potchefstroom, a distance of 113 miles. A difficult road was selected, in places traversing the worst type of farm roads. The distance was covered comfortably in six hours. This included several stops as the road, where it traversed fairly deep dongas, had to be reconnoitred by the drivers, before the lorries could be taken through. A steady speed of 30 miles per hour was maintained, and, for testing purposes, the speed was increased to 40 miles per hour. Top gear was used for the entire journey, except for one particularly bad stretch of track, where second gear was used, and the speed reduced to 15 miles per hour.

The detatchment on the truck wore goggles, but reported that they were not seriously affected by the dust. Furthermore, they reported that it was quite comfortable travelling, and not tiring, except that it would have been better if a back-rest had been fitted to the seats. The gun itself travelled without shifting or bumping and arrived in Potchefstroom undamaged no adjustments required to the sights.

Major de Villiers considered this form of artillery traction ideal, and this solved the problem of the equipment being jarred. He could advance no criticisms.

At the Artillery practice camp, the Porte was tested in wet conditions over 14 miles. The equipment was proved capable of surmounting all the difficult portions of the route, despite the slippery conditions in some places and the heavy mud in others.

In the opinion of Major W. Kinkead-Weekes, Commanding Second Field Battery, the trip constituted, a very severe test of the travelling capabilities of the equipment and he felt confident that, except in the most exceptional circumstances, it would be able to cope with difficult terrain, without dismounting the gun and limber, especially if the officer or non-commissioned officer in charge took the precaution of doing the 'leading' which was necessary in the worst places.

Prior to the introduction of the Porte, the 'Dragon' Artillery tractor had been used for traction of 18pounders. At the 1938 Potchefstroom Camp for the 2nd Field Battery one section was employed 'Porte' and the other Dragon-drawn. The difference in the manoeuvrability of the Porte section was very marked, and this section was always 
used when speed of movement was required. During advances, when continuous support was required, this section was used for leap frogging forward, and the guns got to the rendezvous at the same time, if not before, the staff.

It was found that the trucks could move over any ground on the Potchefstroom range, and no difficulty was experienced. Two minutes were needed to get the gun on and off the truck. This was done on the position of assembly when going out of action (about 200 yards clear of the gun position) and on a preliminary position (about 200 yards from the actual gun position) when coming into action.

At the rendezvous, ammunition was removed from the boxes on the truck, and any expended from the limber replaced, the idea being to keep the limber full of ammunition for as long as possible. At the limber line, again, the ammunition boxes on the ammunition carrying trucks, and when necessary, the full limbers carried on the ammuntion trucks, could replace the empty limbers carried on the gun trucks.

As each sub-section was now a complete fighting unit, carrying its own ammunition, the ammu- nition carrying trucks when empty, could be sent back to the ammunition refilling points, and, owing to their speed, rejoin the Battery limber line when ammunition had been replaced.

By April 1939 all field batteries were issued with six Porte lorries which saw service throughout the East African and Abyssinian campaigns.

In 1938 New Zealand introduced a Porte which carried both the gun and a tractor, while towing the limber. No seats were provided for the members of the detachment, nor were arrangements made for their kit. Major de Villiers considered their arrangement unsuitable as no ammunition was carried on the truck but was carried in the limber towed by the truck. This rather defeated the idea, as it was not aimed at towing anything. as towing reduces the speed of a truck. It was also quite unnecessary to carry a tractor, as the truck could take the gun practically anywhere.

Captain R. Harrison of the 11th Field Battery, SAA was one of the many artillery officers who in 1940 pointed out that the type of commercial lorry used for this purpose could not be expected to perform tasks for which it was never intended. He felt it should form the basis for the

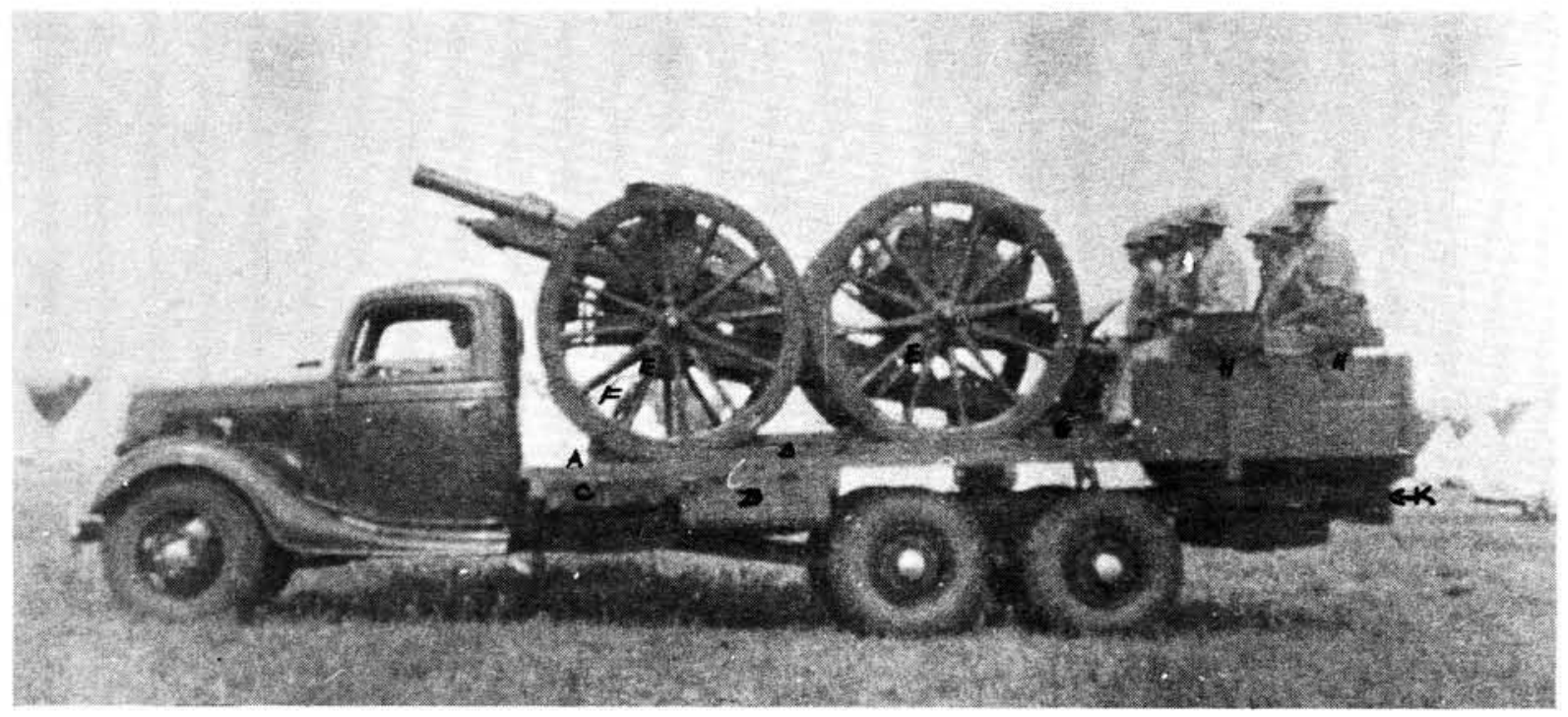

A. 5 ton Power Winch, driven by engine of truck.

B. $U$ Iron channelling, bent at front to take wheel.

C. Box for 5 rounds ammunition. (On either side)

D. Box for 12 rounds ammunition. (On either side)

E. Bottle-screws, hooked to drag washers of wheels, holding them down and forward.
F. Hook on front end of trail for attaching cable of winch.

G. Ramps housed when not in use.

$H$. Removable seats.

K. Limber-hook.

The Ammunition-carrying trucks (one per section) were identical, two ammunition wagons being carried on each. 
design of a lorry built for military use which could give some protection to the engine and radiator. a greater clearance, more robust springing, better electrical equipment, and standard fittings for the equipment, spare water, petrol and oil.

By September 1940 calls had been made for the abolition of the Porte method of conveying guns. The Director Field Army Artillery however pointed out that no case had been made out for the abandonment of Porte for field guns, although a case had been made out that the vehicle used was not suitable for the purpose. The Staff Officer ' $T$ ' at Artillery Training Centre suggested that the Marmon Herrington which had been adapted as an armoured car was an ideal type of vehicle, but this suggestion never appears to have been followed upand the Porte system for field artillery was scrapped mainly because of the absence of a suitable vehicle.

\section{Modern Artiilery:}

During the years following World War II a number of tactical experts predicted the gradual disappearance of the classic artillery as a support weapon. The number of those who saw the future in surface-to-surface missiles and self propelled (SP) systems grew steadily. However, the towed artillery is still with us today and looks set to stay. ${ }^{1}$

The attention of armament producers in the West is today focussed on $105-\mathrm{mm}$ and $155-\mathrm{mm}$ classes with these two able to supply most artillery needs.

The 105-mm gun is considered an extention of the infantry. The need exists that this gun should possess high mobility and for this reason it must be helicopter-transportable. The ROF 105-mm Light Gun used by the British is capable of firing a $16 \mathrm{~kg}$ shell to a maximum range of $17,2 \mathrm{~km}$. The gun has a maximum rate of fire of $6 \mathrm{rpm}$ and a sustained rate of $3 \mathrm{rpm}$. It is produced from a special steel which gives it considerable strength whilst keeping the total weight down to $1861 \mathrm{~kg}$. It is possible to transport the gun in two positions, firstly with the barrel in the firing position and secondly with the gun muzzle swung to the rear and clipped onto the trail. The detachment of six can bring the gun into action in one minute in the former case and two minutes in the latter. In fulfillment of one of the main needs of the class, it is possible to carry the 105-mm gun underslung by a Puma. The normal method of towing is to use a one tonne long wheelbase landrover. While a modern light gun is capable of achieving a maximum range of between 11 and $17 \mathrm{~km}$, depending on the ordnance, it must be remembered that range is not always the primary requirement for infantry fire support and that the emphasis is on versatility and high mobility.

Although the $105-\mathrm{mm}$ gun supplies the high mobility needs of the artillery, the objectives of the $155-\mathrm{mm}$ are somewhat different. This general support type of weapon is the 'heavy fist' at the disposal of the commander. With fewer guns available to cover a potential front, the $155-\mathrm{mm}$ class with its heavier shell and range varying between 20 and $30 \mathrm{~km}$ presents a most attractive weapon.

The first major innovation in the field of auxilliarypropelled $155-\mathrm{mm}$ howitzers came from the Swedes with the Bofor $\mathrm{FH} 77$ which used its engine to drive hydraulic pumps and motors which produced propulsion, elevated and traversed the gun, lifted the auxilliary wheels, extracted the spades, rammed the shell and performed various other tasks. The cheaper FH77B which has since been produced which consists of certain economies with the sights and the substitution of a conventional breech with screw block in place of the sliding block breech.

The FH77 was followed by the Anglo-GermanItalian $\mathrm{FH} 70$ which is now in regimental service. The maximum range of this weapon is in the region of $24 \mathrm{~km}$ with a conventional shell but a rocket-assisted projectile being developed will increase this to more than $30 \mathrm{~km}$.

The French have developed the 155-mm CT towed gun which uses the same barrel and breech mechanism as the GCT 155-mm SP gun which is now in service, the first complete regiment having been equiped at the beginning of 1981

All of these weapons are capable of high rates of fire with the 155-mm GCT being abel to get off five rounds in 45 seconds; the $155-\mathrm{mm}$ CT three in 12 seconds, the $\mathrm{FH} 70$ three in 13 seconds, and the $\mathrm{FH} 77$ three in eight seconds. It seems highly unlikely however that rates of fire anywhere in this region can be maintained or used to often since the heat build-up in the recoil system must be considerable and no recoil system can stand up to this kind of sustained treatment. 
These guns have however reached what is almost their limit in advances as they already have a mass of approximately 10 tons, which is considered a practical limit. Greater ranges are however definite possibilities with further developments in the ammunition field. An increase in terminal effect can be achieved by using better grades of steel for the projectile body and more brisant explosives for the payload, allied, perhaps, with more elegant fuzing systems, all of which tends to be expensive but cost-effective.

An increase in range can on the other hand be achieved by rocket assistance, base bleed, or fin-stabilised sub-calibre projectiles; however, all of these solutions have their adherent problems Rocket assistance often leads to a reduction in accuracy while sub-calibre solutions reduce the payload, are inevitably expensive because of intricate engineering, but are generally accurate. Base bleed appears to offer the best solution in terms of cost, range and terminal effect. The payload is hardly decreased and it presents a much easier engineering proposition than either of the others. The increase in range is however not so great. Developing the most effective design is not a simple matter and can take a lot of time and testing before an acceptable design is developed.

The most effective short-term solution to the problem of achieving longer range has been to perfect the 'Hemispherical base' shell in which the exterior contour is more or less that of a conventional streamlined shell, in which the streamlined portion of the base is shaped internally to form a hemispherical recess.

Careful design of the recess and the streamline taper can make a significant reduction in base drag with a resultant increase in maximum range of some seven to ten per cent.

A longer than usual shell with a fine ogival taper and with aerofoil wing stubs on the body, which help to stabilise the extra length and also give some degree of aero-dynamic lift during flight which helps to extend the range, is a solution displayed by PRB of Belgium. This is called the 'Extended Range Full Bore' (ERFB) projectile. An increase in range from $21.7 \mathrm{~km}$ to $25 \mathrm{~km}$ for the $\mathrm{FH} 77$ and $22.1 \mathrm{~km}$ to $26 \mathrm{~km}$ for the $\mathrm{FH} 70$ is claimed

SP versions of the $\mathrm{FH} 77$ and $155-\mathrm{mm} \mathrm{CT}$ are already in use and a SP version of the $\mathrm{FH} 70$ is under development. All of these make a real contribution to the mobility of the Artillery at the disposal of their armies.

\section{South African Artillery:}

The South African Artillery (Field) is equiped with two World War II guns, namely the 25-pounder and the 5.5" guns. Its other armament includes the G-5 and the 127-mm multiple rocket launcher (MRL). This means that although the two recent additions take care of most shortcomings in their respective spheres, certain problems still remain in giving the South African Army adequate Artillery support.

As was pointed out in a recent edition of 'Armed Forces $^{2}$. South Africa is in need of SP artillery. The obvious solution to this problem is a SP version of the G-5, but this is not as simple in reality. The GCT $155-\mathrm{mm}$ and the SP version of the $\mathrm{FH} 77$ are both mounted on tracked chasis, in the former instance that of the AMX-30 tank and if this example was to be followed, the result would suffer from the same limitations as a main battle tank. As suggested ${ }^{3}$ it might be an idea to make use of a wheeled chasis such as that of the Ratel. The development of a weapon such as this would however inevitably take a certain amount of time and in the meanwhile an interim substitute must be found. (For remarks iro the SP G6, see under footnote 3 .)

The 127-mm MRL appears to be as effective as other weapons in its class but will at the same time suffer from the same inadequacies namely relative inaccuracy, lack of penetration, lengthy re-loading interval and bulky ammunition. The lack of penetration will become of even greater importance as SWAPO improve even further on their dug-in defences. The answer to this prob$\mathrm{lem}^{4}$ lies in using MRL's for the bulk of the preparation, firing only a few salvoes before the conventional artillery concentrates heavy fire on hardened and point targets. They could then again be used to deliver a massive final blow immediately prior to the break-in. This would keep the enemy from taking any effective action until the attackers were upon them. The best result of these tactics would be to limit the warning reaction time of the enemy, with the added bonus of the artillery being able to concentrate on a small number of targets which would ensure their destruction or neutralization.

It has been mentioned in the media that the 140$\mathrm{mm}\left(5.5^{\prime \prime}\right)$ gun has been used in recent South African incursions into Angola. This being so, the 


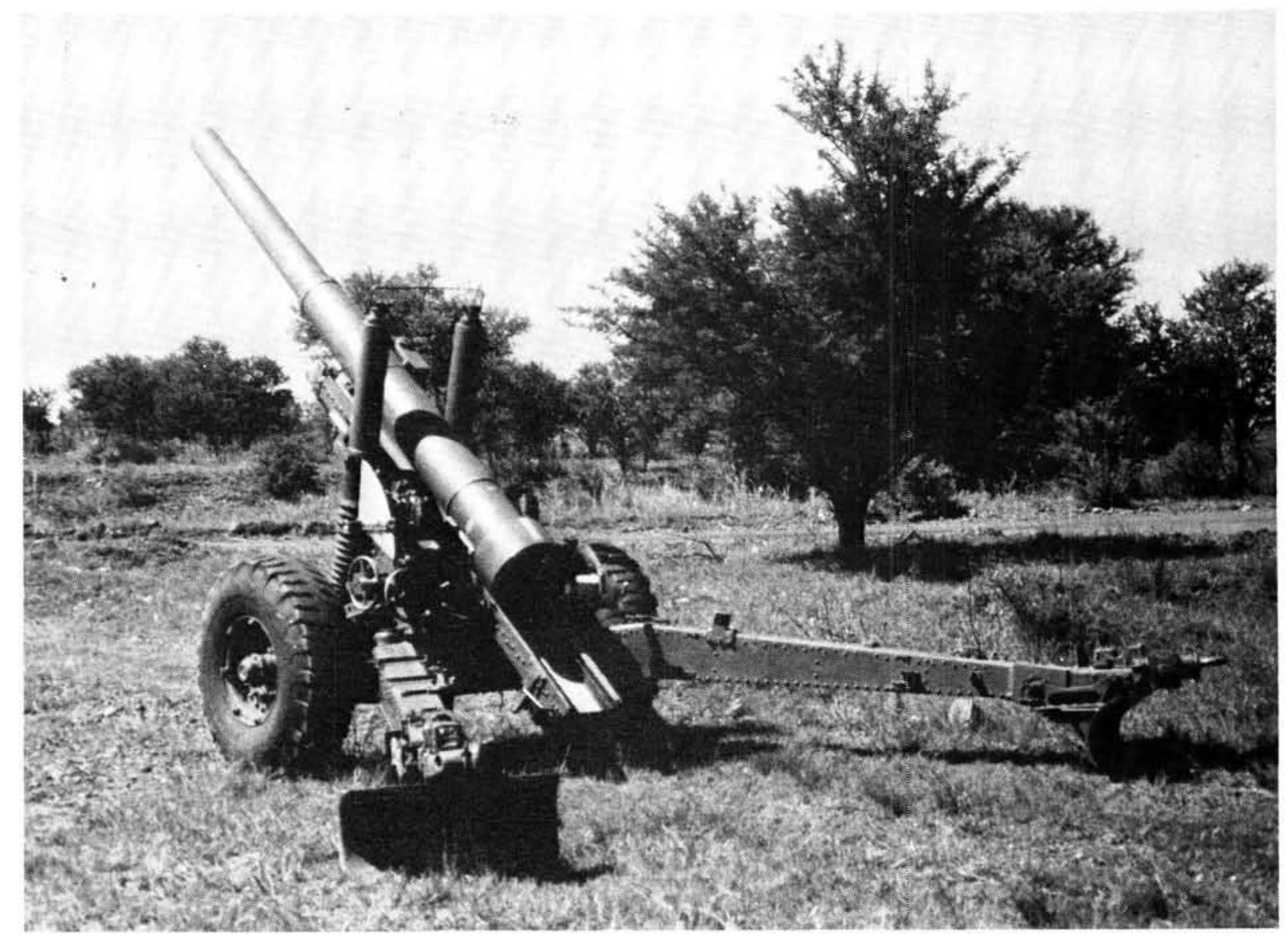

140-mm gun

best method of utilizing this gun ought to be considered.

The $140-\mathrm{mm}$ is too heavy to be considered ideal for the role of infantry support in the modern sense and even during World War II was used mainly in support of armoured regiments. No alternative is however available as the 25pounder is even further from the ideal. Using a conventional $H$.E. shell, the $140-\mathrm{mm}$ has a range of $16,5 \mathrm{~km}$ which, although considerably less than that of the $155-\mathrm{mm}$ 's already mentioned, could be increased somewhat in the ways already suggested.

One of the problems facing South African mechanized columns venturing into Angola to attack SWAPO bases is that of speed and the echelon most likely to present problems is the artillery. A SP $155-\mathrm{mm}$ would solve the problem but as this is not available the $140-\mathrm{mm}$ has to be taken and adapted.

Until recently the best means of transporting the $140-\mathrm{mm}$ was to tow it with a Margirus Deutz but since the introduction of the Samil 100 gun tractor, this presents a far more attractive alternative and has in fact been used for this purpose.

A possible solution to the problem might be to carry the 140-mm 'Porte' on the Samil 100. This would relieve the problem of towing the gun which it has already been mentioned is not an ideal means of transporting a gun and even at the best of times, the cross-country mobility of any towed gun is usually in doubt. Southern Angola is undoubtedly difficult terrain over which to tow a gun.

The Samil 100 gun tractor was developed to tow the G-5 and has a crew compartment for eight persons behind the driver's cab. An observation hatch is fitted centrally in the roof of the crew compartment as well as a machine-gun mounting platform. The section immediately behind the crew compartment consists of a cargo dropside body with built-in storage compartments for gun charges and winching equipment. On the top of these compartments storage is provided for 15 projectile pallets, each weighing $189 \mathrm{~kg}$. 


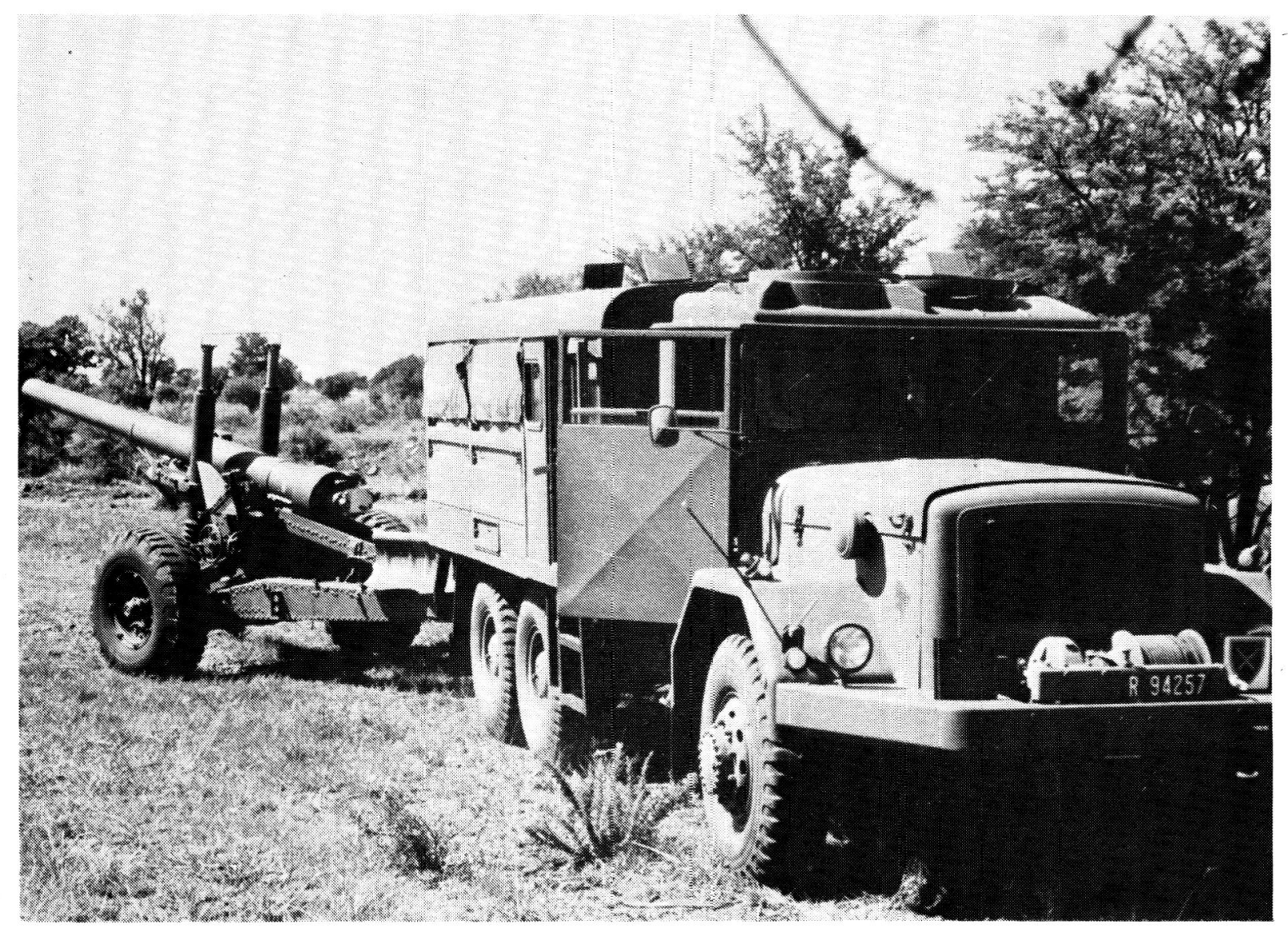

Alternative methods of towing the 140-mm gun. (above) - Marguris Deutz. (below) - Samil 100

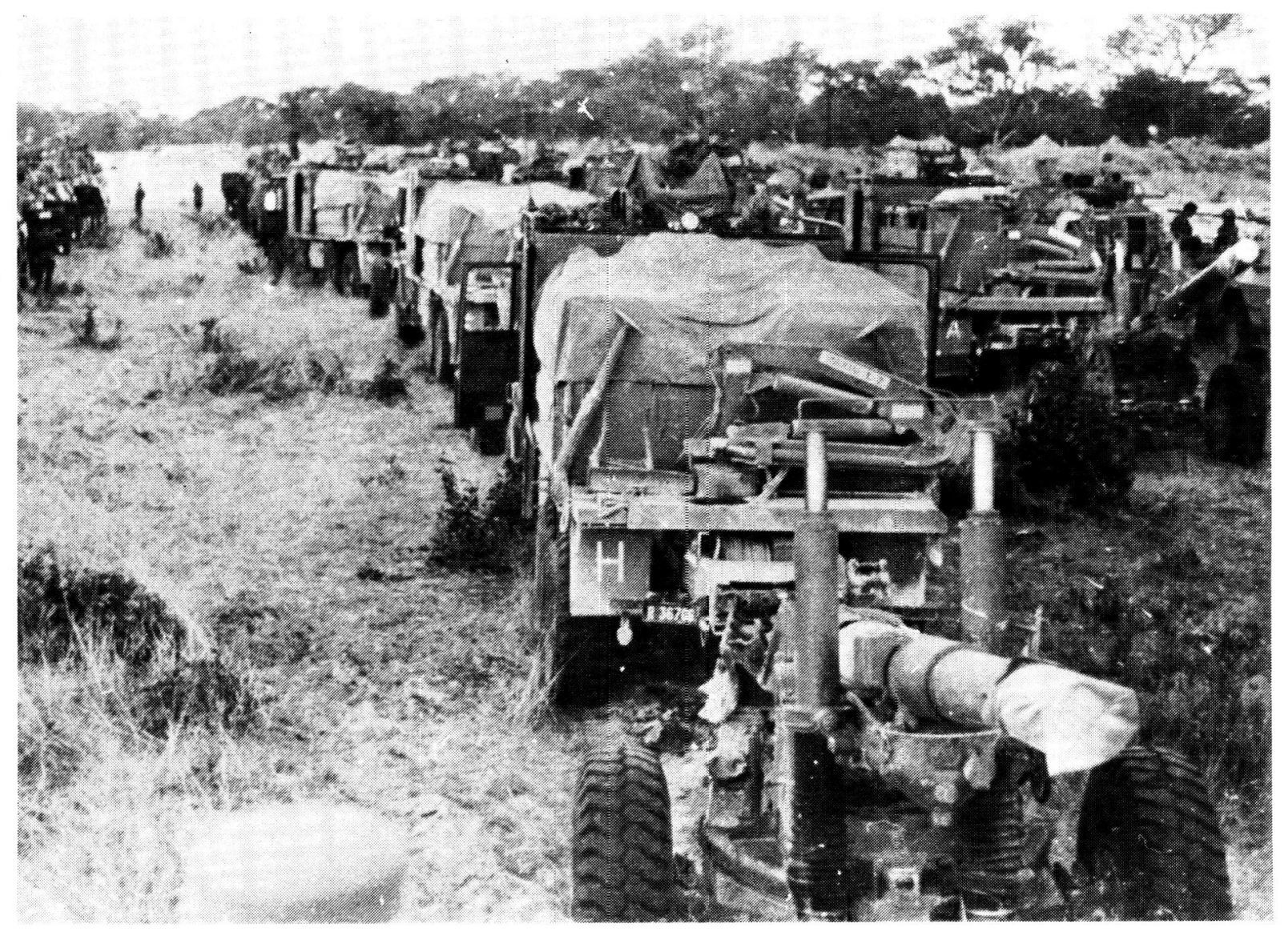


A canvas cover is supplied to cover all equipment on the cargo body. An elephant trunk-type hydraulic crane is mounted behind the rear cargo body, capable of swinging through 360 degrees and lifting $800 \mathrm{~kg}$ at a jub length of 3,5 $\mathrm{m}$. The overall dimensions of the vehicle are 2,5 $\mathrm{m}$ wide $\times 9,35 \mathrm{~m}$ long $\times 3,35 \mathrm{~m}$ high .

The adaptation of the Samil for use as a Porte would not be difficult and would be quite similar to the World War II version. The crane would have to be placed between the cab and the crew compartment, a position from which it would be almost as efficient in operation as its present one. As this gun is quite capable of operating with a crew of four, the cab would be cut to half its present size with a full length bench on the remaining side. The winch for getting the gun onto the tractor could fit under the seat of the crew compartment which would require a slight groove built-in to accommodate the barrel. Ramps for running the gun onto the tractor could be placed under the wheel grooves which would have to be built onto the body and then run out when necessary. To prevent the trail of the gun digging in while being off-loaded, a bar would have to be passed through it with wheels settling in the grooves while travelling and running in the ramps while off-loading. The main problem created by transporting the $140-\mathrm{mm}$ porte would however be that of the positioning of the projectile pallets.

Despite the problems facing the South African Artillery, the situation is far from hopeless and the equipment is far from being as out-moded as it is often depicted.

The lack of a viable light gun is undoubtedly a problem as the 25-pounder is unable to fulfill this role, but the production of an efficient SP 155$\mathrm{mm}$ and a reliable light gun will put South Africa on an equal footing in terms of conventional artillery, with the leading nations of the world. In the interim however, a suggestion such as the one advanced above could provide a viable answer.

South Africa has always been highly respected in military circles for the quality of its manpower and, in the long-run, (when all is said and done) is this not the crux of South Africa's answer to any weapon deficiencies?

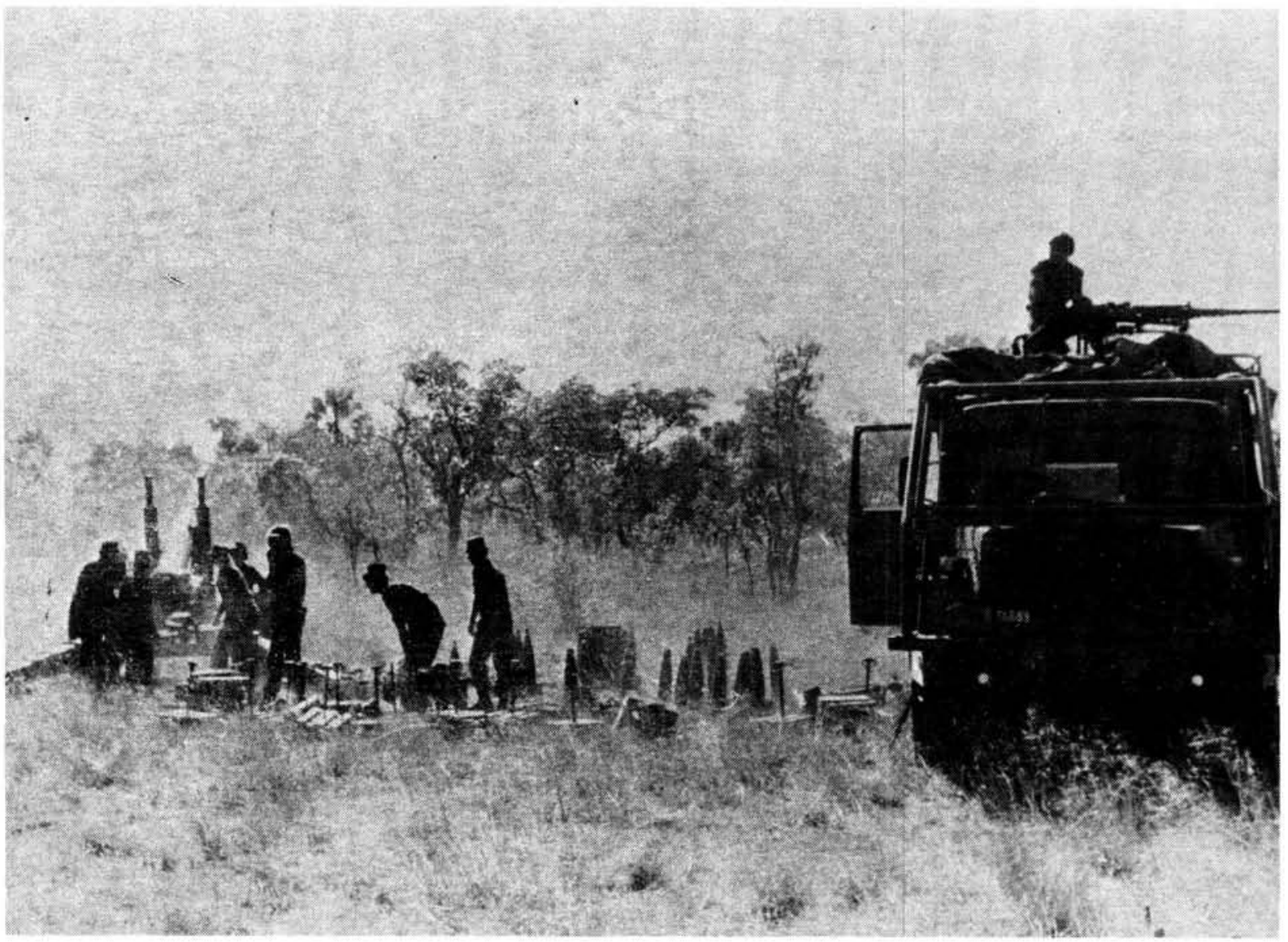

A 140-mm gun in action 
*Sat AC Lillie is attached to the Military Information Bereau and is studying for the B Journ degree at Rhodes University. With this article he won the third prize in the Military Essay Competition of 1981.

\section{Footnotes}

1. Heck, R. "Artillery - An old Weapon with New Technology Inputs" Armada International August 1981 p. 48

2. Heitman, H-R. "Artillery Apolications" Armed Forces Oct 1981

3. ibid.

When this article was entered for the Military Essay Competition in 1981. details of the prototype SP G6 version were still classified. The new system consists of a G5 cannon housed in an armoured-plated turret which is mounted on a SP six-wheeled undercarriage. The wheel concept gives the G6 an improved strategic mobility in respect of speed (max $90 \mathrm{~km}$ per hour). firing range (effective up to $40 \mathrm{~km}$ ), and general mobility.

4. Heitman, H-R. "Rocket Systems" Armed Forces May 1977.

\section{Bibliography}

Armed Forces September 1980 "Ubique".

Armed Forces August 1981 "The New Generation of South African Military Vehicles'

De Villiers, M. "Those Were The Days" Kommando June 1953

Heck, R. "Artillery - An Old Weapon with New Technology Inputs" Armada International Volume 5 No. 4 August 1981.

Heitman, H.R. "Rocket Systems" Armed Forces May 1977.

Heitman, H.R "Artillery Applications" Armed Forces October 1981.

Hogg, I. "Current Trends in Artillery" Defence Vol 12 No. 7 July 1981

Hogg, I. "French Artillery in The 1980's" Defence Vol 12 No. 7 July 1981.

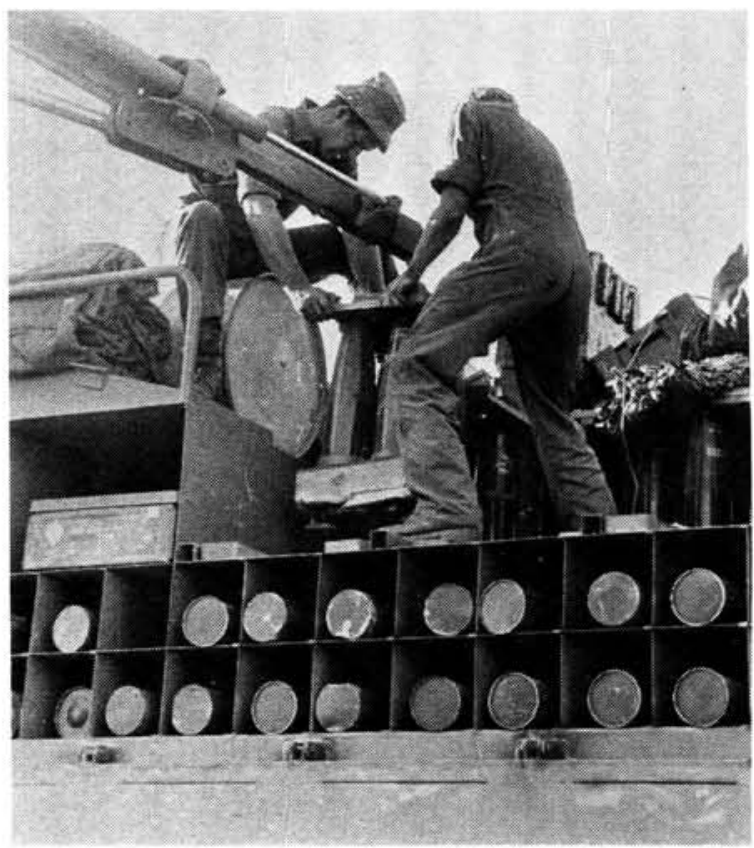

Projectile pallets being loaded

Below: Samil 100 Gun Tractor

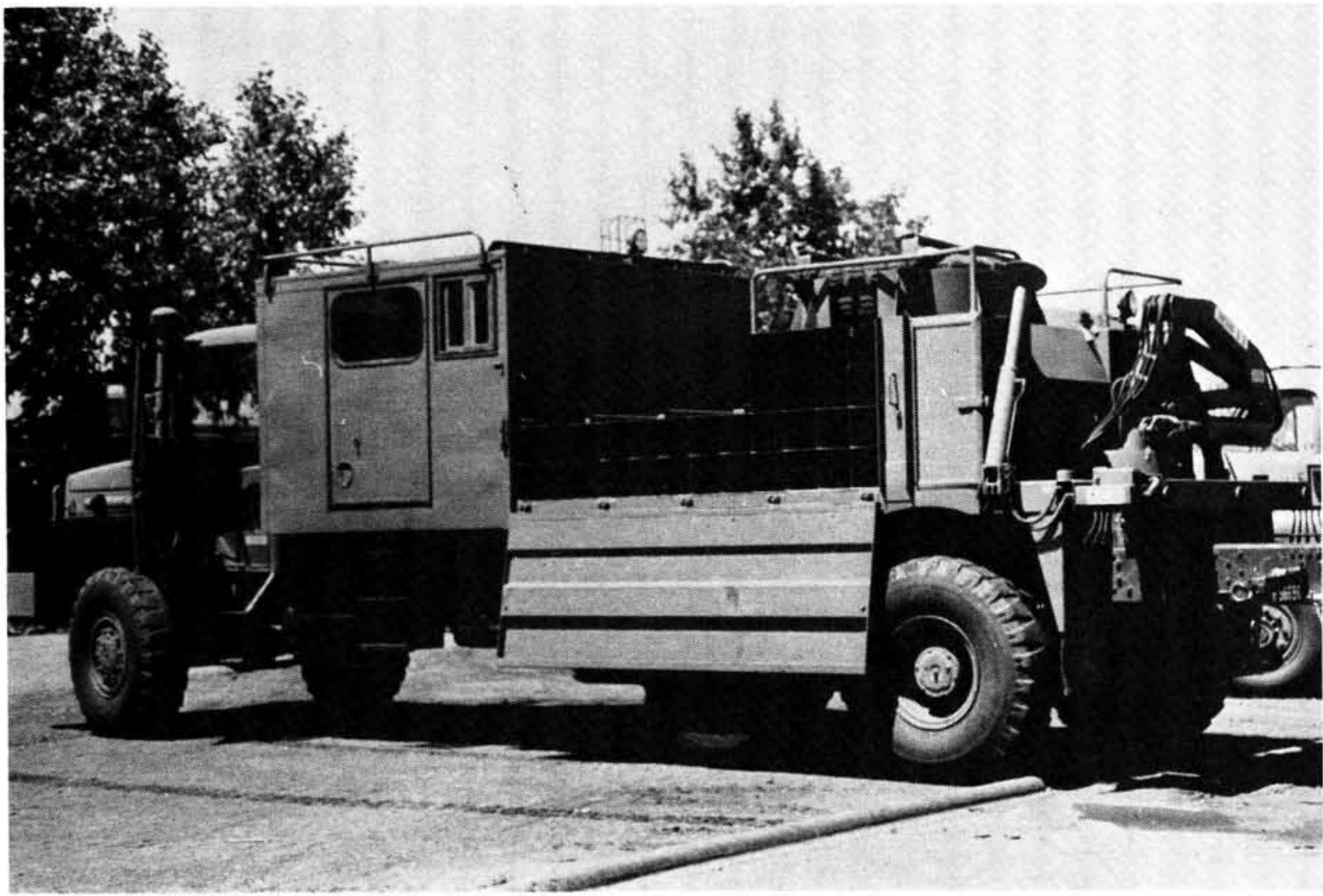

